\title{
IMPACT OF CORONAVIRUS COVID-19 ON THE FOOD SYSTEM
}

\author{
Eulalia Skawińska1凶, Romuald Zalewski \\ 1 University of Zielona Góra, Poland \\ ${ }^{2}$ Commission of Commodity Science Polish Academy of Sciences, Poland
}

\begin{abstract}
The article contributes to the theory of sustainability. It aims to analyse the impact of COVID-19 on global food security and its role in changing food supply chains, with a particular focus on international chains. The research is presented in several sections. The analytical portion discusses the impact of the SARS-CoV-2 epidemiological crisis on the global food market. The state of food safety is then presented, taking into account the quantitative and qualitative aspects. Next, the aspect of the economic availability of food is examined, as well as the important role that international food chains play in shaping food safety. All sections include the results of an analysis of international secondary data on food security under the influence of an ongoing pandemic. The stated objective of the work was achieved and the questions that formulate the research problem were answered. Finally, the need for further normative studies was identified.
\end{abstract}

Key words: food systems, COVID-19, supply chains, food security, world trade

JEL codes: I31, Q17, Q18

\section{INTRODUCTION}

In 120 years, the world economy has been ravaged by two world wars, several economic crises (1929-1932, 2002-2004, 2008-2011), the fuel crisis (1969-1970) and several pandemic events (Spanish influenza 1918-1920; Hong Kong influenza 1968; SARS 2002, EVD 2013-2014). Humanity is currently struggling with the COVID-19 pandemic. Each pandemic has always caused panic, then mobilisation to fight at the medical and economic level, and then relaxation. We are now at the beginning rather than closer to the end. If we take into account the still frequent political instability, wars (e.g. Syria, Libya, Iraq), as well as environmental disasters (floods, fires, volcanic eruptions, water poisoning, droughts, etc.), we are faced with constant crises and struggles of food systems in the implementation of the food security of societies [Żukrowska 2018].

According to Gołębiewski, "The food system covers the movement of raw materials and products from the supplier of raw materials for agricultural production and the farm, through food industry enterprises (primary and secondary processing), distribution sectors (wholesalers and retail stores), to final consumers [Gołębiewski 2019, p. 39]. In this paper, the subject of scientific research and reflection is the flow of food products from field to consumer during the pandemic period of COVID-19. The research problem of this work, on the other hand, is the question: In what links in the food chains are found the greatest threats to food 
safety? What is the role of institutional links in food systems in shaping food safety? Does the reduction in international trade flows of goods and services during the pandemic also affect food trade? The aim of the article is to conduct a preliminary analysis of the effects of COVID-19 on shaping global food security and the role of changes in food supply chains in this process, with a particular focus on international chains. To this end, literature on the subject and other secondary sources were analysed, and comparative, description, and simple statistical techniques were used. The limitation for studies and inferences was the short analysis period, and the fact that little to no 2020 data is yet available.

\section{THE IMPACT OF COVID-19 ON GLOBAL FOOD TURNOVER}

Coronavirus COVID-19 hit China in the autumn of 2019 and spread speedily all over the world. It has brought considerable suffering for many people and huge economic disorder: quarantines, restrictions on travel, factory lockdowns, declines in many service sector activities. All of this has speedily and strongly affected national economies and the global economy. It is impossible at this time to assess the economic consequences of the pandemic, because the situation is evolving by the day and a second wave is very plausibly on its way, soon [OECD 2020]. According to Boone et al.,"The main question for the economic outlook is for how long and how widely the virus will spread, and with it the containment measures. At this stage, there is little certainty on this, so we draw a best-case scenario and a downside scenario" [Boone et al. 2020, p. 37]. Note that the COVID-19 pandemic is all-encompassing in its vastness, its pace of spread, its surprise at the lack of preparation of such a scenario, and thus its inability to counter act in a short period of time and the limitedness of defence resources. It is called in the literature "black swan" because of a sudden, not foreseen event, the appearance for the first time and having catastrophic consequences [Mączyńska 2020, Romanowska 2020]. Moreover, it is difficult to predict its end and consequences, much less accurately counteract it. Its social and economic impact is unknown.

In the example of previous experience, it is known that a pandemic, like many other economic phenomena (e.g. demand curve) and physical phenomena, has as a function of time as a single-modal curvilinear course, the bell shape. However, its course in the form of local increases or decreases is influenced by external factors [Osenton 2004]. In the case of a pandemic, these are deliberate actions such as isolation, social distance, prevention, treatment, social discipline, etc. Each action also has a different geographical dimension and inequality over time. The current pandemic has had a huge impact on the functioning of humanity. In this article, we will highlight aspects related to food safety that we understand as "food safety" and "food security". The specific significance of the work and the research problem is due to the high imbalance between global economies in terms of food safety as demonstrated by the Global Food Safety Initiative - GFSI (Table 1). Of the 113 countries surveyed by the GFSI, $88 \%$ say they have sufficient food supply. However, in 44 countries, $12 \%$ of the population suffers from malnutrition [Economist Intelligence Unit 2019]. There is a worrying assumption that COVID-19 will exacerbate these disparities.

The overall score for GFSI $(0-100)$ is calculated as a weighted average of three categories: affordability, availability and quality plus safety.

Table 1. Global Food Security Index 2019 for the countries with the highest and lowest supply

\begin{tabular}{lll}
\hline Rank & Country & Score \\
\hline 1 & Singapore & 87.4 \\
\hline 2 & Ireland & 84.0 \\
\hline 3 & United States & 83.7 \\
\hline 5 & Switzerland & 83.1 \\
\hline 5 & Finland & 82.9 \\
\hline$\ldots$ & Norway & 82.9 \\
\hline 108 & Madagascar & 37.9 \\
\hline 109 & Chad & 36.9 \\
\hline 110 & Democratic Republic of the Congo & 35.7 \\
\hline 111 & Yemen & 35.6 \\
\hline 112 & Burundi & 34.3 \\
\hline 113 & Venezuela & 31.2 \\
\hline
\end{tabular}

Source: Global Food Security Index database. 


\section{FOOD SAFETY, PRODUCTION VOLUME AND QUALITY}

Food safety and food quality are now, in the time of COVID-19, at the centre of interest. This is in line with the growing position of safety in other areas such as workplace safety or environmental protection. Both safety and quality, are, in this case, inseparable. The term "food safety" from the position of natural or medical sciences, food technology or quality management describes various aspects of health: probability of illness, poisoning or injury as a consequence of consuming a particular food [FAO/WHO 2003]. The meaning of food safety from the perspective of economy (social science) is understood mainly as security of production, supply chain coordination, food availability, continuity and sufficiency for consumer.

The issues connecting food safety and food security, as non-separable parts of the food system, were separated by the Food and Agriculture Organization of the United Nations into four pillars: (1) availability (e.g. food supply); (2) access (economic and physical); (3) utilisation (e.g. biological processing influencing nutritional and dietary properties) and (4) stability over time [FAO 2008, Devereux et al. 2020]. Food is a necessary everyday commodity and its parameters are evaluated from the position of both the customer (subjective quality, narrow sense of safety) and the producer/supplier (objective quality, broad sense of safety). Food safety policy has been described as a construct of voluntary, mandatory and supplementary systems acting along the food value chain and being under the impact of world institutions (e.g. UN, WTO, FAO, ISO, government institutions, official food control). The food system is very flexible and can be shaped by actual needs and requirements. The role of official control authorities who can mould the shape of the system in a given country is very important.

The food chain has been described as combination of security of production, security of supply chain coordination, availability, continuity and sufficiency for the consumer and the industry. Various available data strongly suggest the need to reduce the amount of food losses and waste in various links of the food production chain. In addition, construction of sustainable food systems on local, regional and global levels is strongly recommended. Food safety and a sustainable food system all belong to so-called wicked problems [Dentoni et al. 2012], which are composed of many independent and dependent variables being in a certain state of equilibrium. The task for the future is to try to modify and improve the relations between these variables at the most desirable level. The following is the impact of COVID-19 on market phenomena that directly and indirectly shape food security (Table 2).

Food chain models and institutions of policy intervention are important in each country. These chains "cover three sectors of the economy, i.e. agriculture, food industry and retail [own translation]" [Gołębiewski 2019, p. 156]. As Gołębiewski points out, consolidation in food supply chains, and in particular in some sectors of the processing industry and trade, has played an increasing role in shaping it, which has fostered their lengthening and internationalisation (KTN share) [Gołębiewski 2019]. The participating entities benefited from a cost competitive advantage resulting from the scale of turnover. This has led to increased risks for operators and destabilisation of food markets, large food losses during transport, storage and bacteriological or viral disturbances [Smoczyński $2020]$ and reduced consumer confidence. Food chain models and national policy intervention institutions are important in each country.

Alternative food systems, based on a close link between food production and the local, cultural and social environment, play a major role in the epidemiological crisis. Then there are shorter supply chains in terms of geographical distance and number of links present. This increases the speed of supply, the diversity and freshness of products and reduces their contamination as well as losses. It also creates a lower burden on the environment by saving the consumption of resources (energy, transport), and promotes the development of organic food production and its waste reduction [Gołebiewski 2019]. The "larger the scale of production, the greater the ecological costs [own translation]" [Sadowski 2018, p. 107]. This also increases the share of local product brands in sales, which positively affects their recognition and consumer loyalty, thereby stimulating producers to invest more in shaping a qualitative competitive advantage.

Supply chains are fundamentally influenced by consumer preferences. There is a significant shift in consumer behaviour on the world market towards the 
Skawińska, E., Zalewski, R. (2020). Impact of coronavirus COVID-19 on the food system. Acta Sci. Pol. Oeconomia 19 (4), 121-129, DOI: 10.22630/ASPE.2020.19.4.48

Table 2. Manifestations of COVID-19's impact on the food market in the first half of 2020 (March-August)

\begin{tabular}{|c|c|}
\hline Phenomena that shape demand in the food market & Phenomena that shape supply in the food market \\
\hline Decrease in the degree of professional activity & Violence in food production \\
\hline Increase in the unemployment rate & Changing the supply structure of food products \\
\hline $\begin{array}{l}\text { - Reduced availability of jobs } \\
\text { - Reducing the income of the population }\end{array}$ & $\begin{array}{l}\text { Changing supply chains (shortening their length, changing } \\
\text { the supply structure for domestic benefit) }\end{array}$ \\
\hline Increase in food cost inflation & $\begin{array}{l}\text { Reduction of expenditure on food quality in the logistics chain } \\
\text { (warehousing, transport, limited quality control) }\end{array}$ \\
\hline Decrease in purchasing power of the population & $\begin{array}{l}\text { Failure to meet delivery deadlines (broken contracts, bankruptcy } \\
\text { of companies in the distribution chain, etc.) }\end{array}$ \\
\hline $\begin{array}{l}\text { - Changing consumer patterns and attitudes } \\
\text { - Increased demand for organic, fresh and healthy products }\end{array}$ & $\begin{array}{l}\text { Reducing the use of resources (human, building surface) } \\
\text { for the applications of modern technologies }\end{array}$ \\
\hline $\begin{array}{l}\text { Trust as the first criterion for the choice of food products } \\
\text { by consumers (preferred quality, reliable origin, low environmental } \\
\text { burden) }\end{array}$ & Broken traditional supply chains and re-modified \\
\hline $\begin{array}{l}\text { Availability of modern technologies as a condition for on-line } \\
\text { purchases }\end{array}$ & $\begin{array}{l}\text { The increasing importance of Corporate Social Responsibility } \\
\text { (CSR) in shaping the competitive advantage of enterprises } \\
\text { in building partnerships in logistics chains }\end{array}$ \\
\hline
\end{tabular}

Source: Authors' own elaboration.

preference of organic and fresh products, which favourably modifies the pattern of trade supply for plant products. The structure of the links in the supply chain has changed. The importance of cargo carriers has increased. These chains have become shorter, they are managed flexibly in response to adapting to changes, and affect the availability of markets in the geographical space. Another issue is the increased turnover of international trade in the financial expression, as their main cause is the inflationary increase in the prices of agricultural raw materials and industrial food processing products in all countries (Table 3 ).

Table 3. FAO Food Price Index ${ }^{\mathrm{a}}$

\begin{tabular}{llllll}
\hline Year & Index & Meat & Dairy & Cereals & Vegetables \\
\hline 2008 & 117.6 & 90.2 & 133.3 & 137.6 & 141.0 \\
\hline 2010 & 106.7 & 91.0 & 111.9 & 107.5 & 121.9 \\
\hline 2014 & 115.0 & 112.2 & 130.2 & 115.8 & 110.8 \\
\hline 2015 & 93.1 & 96.7 & 87.1 & 95.6 & 90.0 \\
\hline 2016 & 91.9 & 91.0 & 82.6 & 88.3 & 99.4 \\
\hline 2019 & 95.0 & 100.0 & 102.8 & 96.4 & 83.3 \\
\hline 2019 Nov. & 98.6 & 106.5 & 102.5 & 95.4 & 93.2 \\
\hline 2019 Dec. & 101.0 & 106.6 & 103.5 & 97.2 & 101.5 \\
\hline 2020 Jan & 102.5 & 103.8 & 103.8 & 97.7 & 108.7 \\
\hline 2020 Mar & 95.1 & 99.5 & 101.5 & 98.7 & 85.5 \\
\hline 2020 Aug & 96.1 & 93.2 & 102.0 & & 98.7 \\
\hline
\end{tabular}

${ }^{\text {a }}$ Weighted with the average export shares of each of the groups for period 2014-2016.

Source: FAO Food Price Index database. 
We conclude that a return to national sources, and from there to local, traditional and therefore internal market attitudes, taking into account cultural conditions in management, is an important direction for changes in supply and supply chains. On the demand side, an important direction of change is the widespread increase in value in health-promoting, organic and fresh products from local, culturally close supplies [Shan and Yang 2020, Wiatrak 2020].

\section{FOOD AVAILABILITY: PHYSICAL AND ECONOMICAL}

To date, there is no information on serious disturbances in access to food on the market caused, for example, by a drastic decline in its production and a shortage on the world market. In highly developed countries, this production is large-scale, mechanised, saturated with harvesting, storage and transport facilities and is sufficient. The obstacles resulting from the need to maintain social distance are not so severe, although they introduce organisational changes. Some difficulties in the labour market during the initial pandemic resulted from the closure of borders and the departure of some seasonal workers or foreigners to their families. "Global food supply depends on millions of migrant workers. In many countries, especially in developed economies, migrant workers play a critical role in agriculture and food production" [IOM 2020]. Data published by the World Trade Organization show that some countries are introducing import facilitations on food by changing certification procedures, relaxing technical standards and exaggerating the level of risk in international trade [WTO 2020]. According to the WTO, information in the first half of 2020, agricultural and food exports increased by $2.5 \%$ during the first quarter of the year compared to the same period in 2019 [WTO 2020]. The COVID-19 pandemic restricts access to food mainly due to lower incomes, reduced demand due to lockdowns or job losses for a significant part of the population. In some countries or social groups, around $70 \%$ of income is spent on food [Laborde et al. 2020]. Temporary state aid only for a short period of time closes this gap. In its published forecast, the
International Monetary Fund predicts a 5\% contraction of the global economy in 2020 [IMF 2020]. This heralds a global recession deeper than in 2008-2009. The OECD, on the other hand, forecasts a $13 \%$ reduction in GDP in 2020 and notes that "keeping trade flowing requires co-operation and trust - for example, that the market will supply essentials, that countries will not impose export restrictions, and that imports do not pose health risk" [OECD 2020, p. 2]. According to the World Bank data, by June 2020 there were few interruptions in food production [World Bank 2020]. However, due to the deteriorating financial situation of households, especially in underdeveloped countries, the number of malnourished people may increase.

Food prices have risen from 3 to $15 \%$ in many countries since the beginning of 2020 and are likely to peak in the second quarter of 2020. They are forecast to decline slowly in subsequent periods ${ }^{1}$. It should be noted, however, that there are also quite a few countries where food price growth exceeded $20 \%$ in Q2 2020 (e.g. Ethiopia, Iran, Liberia, Haiti) and even more (Argentina 46\%, Suriname 56\%). Absolute exceptions include hyperinflation in Zimbabwe with an increase of $836 \%$, and Venezuela with 2,200\%).

Overall, the food price increases in European Union countries in April 2020 were unusually strong and reflected an unprecedented combination of demand and supply influences. However, the Harmonised Index of Consumer Prizes (HICP) for food in May and June signalled signs of normalisation in price changes as lockdowns eased and activity resumed [Rubene 2020]. Monthly price developments in consumer food prices during the COVID-19 lockdown in the euro area significantly differs. The highest in April were observed for unprocessed food $4 \%$, vegetables $8 \%$, fish $4 \%$ and fruit $3 \%$. In the processed goods group, the increases were much smaller (e.g. bread and pasta by $0.9 \%$ and processed meat by $0.4 \%$ ). Preliminary data for June suggests a slight fall in prices, which means that annual inflation for unprocessed food of $7.6 \%$ in April fell to around $5.9 \%$ in June. It can be assumed that some of the reasons for these changes in the euro area was seasonality, shock resulting from lockdown, increased hygiene restrictions, surge of retail sales, etc.

\footnotetext{
${ }^{1}$ Trading Economics. Food Inflation - Forecast 2020-2022. Retrieved from https://tradingeconomics.com/forecast/foodinflation [accessed 27.09.2020].
} 


\section{INTERNATIONAL SUPPLY CHAINS}

Supply chains are another source through which COVID-19 introduces tensions and threats to food exports and imports between countries. Extending or interrupting them disrupts supplies to food processing or trade companies and increases costs. In marginal cases, it prevents the continuation of production and forces the search for alternative suppliers. Such events undermine the effectiveness of a just-in-time strategy to minimise staple foods in the processing industry (e.g. feed, food oils). At the same time, it leads to disorganisation of markets e.g. vegetables, fruits, fish and other sensitive products. It is likely that such experiences will be used in the future to change the strategy between efficiency and resilience [Fernandes 2020].

To date, there is no information on serious disruptions in the supply of basic agricultural raw materials and food. However, there is no record or certainty that "green lines" have not been introduced in some countries, which have lowered the recommended levels of sanitary and phytosanitary and technical standards for transport, production processes and distribution of agricultural raw materials and food. The OECD document draws attention to the fact that "keeping trade flowing requires co-operation and trust [...] that countries will not impose export restrictions, [...] that imports do not pose health risks $[\ldots]$ avoid escalation of the current trade tensions" [OECD 2020, p. 2]. These chains are most often complex, multi-stage, and in normal times there have been many losses (food waste and food losses) [Hegenshol et al. 2018]. They are estimated to be worth USD 1,200 billion a year and 1,500 million $\mathrm{t}$.

A significant number of interruptions are created in the early stages of the chain and in countries with labour-intensive, traditional and weak agrarian, industrial and transport infrastructure [Tamru et al. 2020]. However, it turns out that also in highly developed countries, supply chains have been disrupted by the epidemic. In Germany (Berlin), more than 3,000 workers in the meat industry (slaughterhouses) have contracted COVID-19, which has made it necessary to reduce production or close down firms completely. This caused considerable market turbulence.

The very significant restrictions on international passenger flights have resulted in the disruption or weakening of numerous food supply chains. For example, the export of flowers from African countries to Europe has ceased altogether, resulting in an increase in female unemployment [Bhalla and Wullbercq 2020]. A similar phenomenon occurred in the export of vegetables, herbs and other goods. According to the International Air Transport Association, air cargo in November 2019 (compared to January 2018, assumed to be $100 \%$ ) decreased to $95 \%$, and in February 2020 it decreased to $88 \%$. Global demand fell by $13.5 \%$ in July 2020 ( $15.5 \%$ for international operations) compared to the previous year. That is a modest improvement from the $16.6 \%$ year-on-year drop recorded in June. Seasonally-adjusted demand grew by $2.6 \%$ month-on-month in July [IATA 2020].

The Institute of Shipping Economics and Logistics reports that maritime transport, which since January 2015 (assumed to be 100\%), in September 2019 had increased to around $116 \%$ and decreased in February 2020 by $106 \%$, while in summer it returned to $116 \%$ [ISL 2020].

For many recent years, modern food systems based on new technologies and techniques, food supply chains and logistics systems have been developing, including: transport, storage and material handling, order handling, stock management [Przybyłowski et al. 1998]. Their operation was possible, on the one hand, through the development of means of transport from road, sea to air, construction of warehouses, cold storage and reloading bases. New technologies and transport equipment were introduced to transport cargo in a wide range of temperatures and humidity. The development of information technologies, especially the Internet of Things (IoT) allowed to optimise conditions and time of transport. Startups play a growing role in handling the food chain [Skawińska and Zalewski 2020]. Despite this, the complex system was quickly infected by COVID-19. Some unfavourable changes are shown in Table 4.

\section{SUMMARY AND CONCLUSIONS}

A preliminary analysis of the effects of COVID-19 on food systems to date suggests that threats to the global food safety system have increased. The main sources of this phenomenon are in the organisation 
Table 4. Restrictions due to COVID-19 affecting transport

\begin{tabular}{ll}
\hline Restrictions / Obstacles & Impacts \\
\hline $\begin{array}{l}\text { Restrictions on passenger flights have reduced the availability } \\
\text { of air cargo }\end{array}$ & Price increases between 30 and $60 \%$ [Curran 2020] \\
\hline $\begin{array}{l}\text { Important ports for trade have reduced transshipment by } 10-20 \% \\
\text { [Baschuk 2020] }\end{array}$ & $\begin{array}{l}\text { - Change of organisational processes } \\
- \text { Bureaucracy } \\
\end{array}$ \\
\hline & - Speeding up certain procedures, e.g. customs [Baschuk 2020] \\
\hline $\begin{array}{l}\text { A significant proportion of containers have been blocked in } \\
\text { Chinese ports }\end{array}$ & - Delay of deliveries \\
& - Increase in prices of transport services, increase in prices \\
& of goods for the customer \\
\hline & - Decreasing labour force \\
Lockdown and/or limits on mobility & - Raising cost due to protective measures \\
& - Difficulties in inspecting goods (e.g. SPS, TBT, anti dumping \\
& etc.).
\end{tabular}

Source: Authors' own elaboration.

of the market, and these are: unstable supply chains, an increase in the rate of cost inflation, a reduction in people's purchasing power, as well as tolerating the failure to comply with quality standards at links in the supply chains. This has resulted in a deterioration in the availability and quality of food for many sections of society. In the absence of food self-sufficiency in many countries, international food supply chains and logistical systems that have been disrupted by the epidemic are very important.

The conclusions of the study, which have been included as sources of threats and opportunities to food security, are presented further.

The greatest risks have occurred:

- in the supply chains as a result of their interruption and change of cooperation partners in transport and in formal institutions connecting the various links in the food chain, which, among other things, prolonged the delivery process;

- in the deterioration of the quality of raw materials and finished products, as a result of time-consuming logistic chains and the lack of rigorous compliance with applicable standards, e.g.: temperature, humidity as good practices in cold chain.

The sources of opportunities should be seen in the following:

- increased rational use of national resources;
- to adapt food production to consumer preferences without burdening the environment;

- the development of innovative regional specialisation in food products.

Eliminating threats and barriers related to food safety requires the use of many tools and instruments in individual national economies and groups of countries with different degrees of integration, e.g. in the EU, as well as at the global level, represented by international organisations [Skawińska and Zalewski 2017]. This direction of ex-post and ex-ante research is urgently awaited as a normative platform. There are voices of prominent economists in the literature to finally include the "brain opener" as early warning thinking [Mączyńska 2020].

\section{REFERENCES}

Baschuk, B. (2020). A Trade Collapse that's Heading into the History Books. Bloomberg, 26 March. Retrieved from https://www.bloomberg.com/news/articles/202003-26/supply-chain-latest-a-trade-plunge-worthy-ofthe-history-books [accessed 26.09.2020].

Bhalla, E. Wullbercq, E. (2020). No bed of roses. East Africa's female flower workers lose jobs as coronavirus hits exports. Reuters, 11 April. Retrieved from https:/tinyurl.com/yyeoyxvy [accessed 26.09.2020].

Boone, L., Haugh, D., Pain, N., Salins, V. (2020). Tackling the fallout from COVID-19. [In:] R. Baldwin, B. Weder 
di Mauro (Eds.), Economics in the Time of COVID-19. CEPR Press [eBook].

Brundtland, G.H. (2019). World at Risk from Deadly Pandemics. GPMB Press Release. 17 September. Retrieved from https://tinyurl.com/y3bc8jmt [accessed 15.09.2020].

Curran, E. (2020). Urgent Demand for Medical Equipment is Making Air Cargo Fees 'Absolutely Crazy'. Bloomberg, 30 March. Retrieved from https://www.bloomberg. com/news/articles/2020-03-30/-absolutely-crazy-aircargo-fees-highlight-supply-chain-squeeze [accessed 25.09.2020].

Dentoni, D., Hospes, O., Ross, R.B. (2012). Managing wicked problems in agibusiness: the role of multistakeholder engagement in value creation. International Food and Agribusiness Management Review, 15 (Special Issue B), 1-12. Retrieved from https://www. ifama.org/resources/Documents/v15ib/Editor-Intro.pdf [accessed 22.08.2020].

Devereux, St., Bene, Ch., Hoddinott, J. (2020). Conceptualizing COVID-19 impact on household food security. Food Security, 12, 769-772.

FAO Food Price Index database. Retrieved from http:// www.fao.org/worldfoodsituation/foodpricesindex/en [accessed 28.09.2020].Food and Agriculture Organization of the United Nations - FAO (2008). An introduction to the basic concept of food security. Retrieved from www.fao.org/3/all936e.pdf [accessed 29.09.2020].

Fernandes, N. (2020). Economic effects of coronavirus outbreak (COVID-19) on the world economy. Retrieved from https://foroparalapazenelmediterraneo.es/ wp-content/uploads/2020/03/SSRN-id3557504.pdf.pdf [accessed 15.09.2020].

Food and Agriculture Organization of the United Nations/ World Health Organization - FAO/WHO (2003). General Principles of Food Hygiene. CAC/RCP 1-1969 (adopt. 1969, amend. 1999, rev. 1997, 2003). Retrieved from http://www.fao.org/input/download/standards/23/ CXP_001e.pdf [accessed 22.08.2020].

Global Food Security Index database. Retrieved from https://foodsecurityindex.eiu.com [accessed 20.09.2020].

Economist Intelligence Unit (2019). Global Food Security Index 2019. Strengthening food systems and the environment through innovation and investment. Report. Retrieved from https://foodsecurityindex.eiu.com/Home/ DownloadResource?fileName $=$ Global $\% 20$ Food $\% 20$ Security\%20Index\%202019\%20report.pdf [accessed 25.08.2020].

Gołębiewski, J. (2019). Systemy żywnościowe w warunkach gospodarki cyrkularnej. Studium porównawcze krajów Unii Europejskiej. Wydawnictwo SGGW, Warszawa.
Hegenshold, E., Unnikrishan, S., Pollman-Larsen, M., Askeldottir B., Gerard, M. (2018). Tackling the 1.6-billion-ton food loss and waste crisis. Retrieved from http:// image-src.bcg.com/Images/BCG-Tackling-the-1.6-Billion-Ton-Food-Waste-Crisis-Aug-2018\%20\%281\%29_ tcm9-200324.pdf [accessed 02.09 2019].

Institute of Shipping Economics and Logistics - ISL (2020). RWI/ISL Container Throughput Index: Revival of world trade continues. 31 August. Retrieved from https://www.isl.org/en/containerindex/july-2020 [accessed 02.10.2020].

International Air Transport Association - IATA (2020). July Air Cargo Demand Stable, Capacity Remains Constrained. Press Release 67, 31 August. Retrieved from https://www.iata.org/en/pressroom/pr/2020-08-31-01 [accessed 15.09.2020].

International Monetary Fund - IMF (2020). World Economic Outlook Update: A crisis Like no Other. An Uncertain Recovery. June. Retrieved from tinyurl.com/yazvtk7d [accessed 17.09.2020].

International Organization for Migration - IOM (2020). Migrants \& global food supply. COVID-19 Analytical Snapshot \#18. Retrieved from https://www.iom.int/sites/ default/files/documents/covid-19_analytical_snapshot_ 18 _-_migrants_and_global_food_supply.pdf [accessed 17.09.2020].

Laborde, D., Martin, W., Swinnen, J., Vos, R. (2020). COVID-19 risks to global food security. Science, 369 (6503), 500-502, https://doi.org/10.1126/science.abc4765

Mączyńska, E. (2020). Strategiczne myślenie jako wczesno ostrzegawczy „otwieracz mózgów”. [In:] E. Bojar (Ed.), Zarządzanie przyszłością. Wyzwania w dobie postglobalizacji. Towarzystwo Naukowe Organizacji i Kierownictwa, Lublin.

Organisation for Economic Co-operation and Development - OECD (2020). Tackling COVID-19. Contributing to a global effort (updated 12 June 2020). COVID-19 Global Pandemic. Joint Statement by the Development Assistance Committee (DAC) of the Organisation for Economic Co-operation and Development (OECD).

Osenton, T. (2004). The Death of Demand: Finding Growth in a Saturated Global Economy. Financial Times Prentice Hall Books.

Przybyłowski, K., Hartley, S.W., Kerin, R.A., Rudelius, W. (1998). Marketing. Oficyna Ekonomiczna, Kraków.

Romanowska, M. (2020). Przyszłość zarządzania, czyli zarządzanie przyszłością. [In:] E. Bojar (Ed.), Zarządzanie przyszłością. Wyzwania w dobie postglobalizacji. Towarzystwo Naukowe Organizacji i Kierownictwa, Lublin.

Rubene, I. (2020). Recent developments in euro area food prices. European Central Bank Economic Bulletin, 5. 
Retrieved from https://www.ecb.europa.eu/pub/economic-bulletin/focus/2020/html/ecb.ebbox 202005 07 174eeeb845.en.html [accessed 25.09.2020].

Sadowski, A. (2018). Gospodarka, rolnictwo i środowisko w wybranych częściach świata. Zagadnienia Ekonomiki Rolnej, 1 (346), 96-112.

Shan, H., Yang, J., (2020). Promoting the implementation of extended producer responsibility systems in China: A behavioral game perspective. Journal of Cleaner Production, 250, 119446, https://doi.org/10.1016/ j.jclepro.2019.119446

Skawińska, E., Zalewski, R.I. (2017). The role of international organizations in international economic relations in context of sustainable development. Acta Scientiarum Polonorum. Oeconomia, 16 (4), 141-149.

Skawińska, E., Zalewski, R.I. (2020). Success Factors of Startups in the EU - A Comparative Study. Sustainability, 12, 8200. https://doi.org/10.3390/su12198200

Smoczyński, S.S. (2020). Wirusowe - chemiczne i biologiczne zanieczyszczenia żywności, w tym mleka i jego przetworów z uwzględnieniem zgrożenia chorobami zakaźnymi. Przegląd Mleczarski, 5, 2-7.

Tamru, S., Hirvonen, H., Minten, B. (2020). Impacts of the COVID-19 crisis on vegetable value chains in Ethiopia. [In:] J. Swinnen, J. McDermott (Eds.), COVID-19 and global food security. Part Five: Supply chains. International Food Policy Research Institute, Washington, DC, 81-83. https://doi.org/10.2499/p15738coll2.133762_18. Retrieved from https://www.ifpri.org/publication/impacts-covid-19-crisis-vegetable-value-chains-ethiopia [accessed 28.09.2020].

Wiatrak, A.P. (2020). Wybrane zagadnienia zarządzania w środowisku lokalnym w okresie globalizacji i postglobalizacji. [In:] E. Bojar (Ed.), Zarządzanie przyszłością. Wyzwania w dobie postglobalizacji. Towarzystwo Naukowe Organizacji i Kierownictwa, Lublin.

World Bank (2020). Food Security and COVID-19. Brief, 15 October. Retrieved from https:/www.worldbank.org/ en/topic/agriculture/brief/food-security-and-covid-19 [accessed 26.09.2020].

World Trade Organization - WTO (2020). Standards, regulations and COVID-19 - What actions taken by WTO members? Information Note, 20 May. Retrieved from https://www.wto.org/english/tratop_e/covid19_e/standards_report_e.pdf [accessed 26.09.2020].

Żukrowska, K. (2018). Turbulencje w międzynarodowych stosunkach gospodarczych i możliwe ich konsekwencje. [In:] A. Stelmach, T.R. Szymczyński, M. Walkowski (Eds.), Stosunki międzynarodowe w procesie zmian. Uniwersytet im. Adama Mickiewicza w Poznaniu, Poznań.

\section{WPKYW KORONAWIRUSA COVID-19 NA SYSTEM ŻYWNOŚCIOWY}

\section{STRESZCZENIE}

Artykuł wpisuje się w teorie zrównoważonego rozwoju. Jego celem jest analiza skutków COVID-19 na bezpieczeństwo żywnościowe na świecie oraz roli w tym procesie zmian w łańcuchach dostaw produktów żywnościowych, ze szczególnym uwzględnieniem międzynarodowych. W jego realizacji zastosowano metody studiów literatury przedmiotu i innych źródeł wtórnych, porównawczą oraz opisu, proste techniki statystyczne, wizualizacji i dedukcji. Struktura pracy składa się z czterech części merytorycznych, wstępu i podsumowania. W pracy najpierw przedstawiono problem badawczy, wagę problemu i rozumienie przyjętych w pracy podstawowych kategorii ekonomicznych. Dalej omówiono wpływ kryzysu epidemiologicznego COVID-19 na światowy rynek żywności. W kolejnej części zawarto stan bezpieczeństwa żywności, biorąc pod uwagę aspekty ilościowy i jakościowy, a dalej aspekt dostępności ekonomicznej żywności. Istotną rolę w systemach żywności odgrywają międzynarodowe łańcuchy żywności przedstawione w kolejnej części artykułu. W wymienionych częściach zawarto wyniki analizy danych wtórnych dotyczących bezpieczeństwa żywnościowego pod wpływem trwającej epidemii. Zakończenie zawiera podsumowanie i wnioski. Sformułowany cel pracy został zrealizowany i uzyskano odpowiedzi na postawione w problemie badawczym pytania. Na końcu wskazano na potrzebę prowadzenia dalszych badań o charakterze normatywnym.

Słowa kluczowe: system żywnościowy, COVID-19, łańcuch dostaw, bezpieczeństwo żywności, handel światowy 